\title{
Tall poppies in the land down under
}

\section{An applied ethnolinguistic approach ${ }^{1}$}

\author{
Bert Peeters \\ Griffith University
}

\begin{abstract}
Most EFL curricula, irrespective of the variety of English they seek to impart, have little time for cultural values, focusing instead on "Culture with a capital C,” i.e., history, geography, cultural heritage, folklore, etc. Applied ethnolinguistics is a relatively new framework that has been developed to curb the trend. It consists of a number of pathways that can be replicated by advanced language students eager to increase their awareness of potentially unfamiliar cultural values. One of the pathways, ethnorhetorics (the study of culturally salient figures of speech), will be illustrated here with data drawn from Australian English. The focus will be on the tall poppy metaphor. A few pointers at its cultural saliency and a brief look at where tall poppies are typically found will be followed by a more linguistically oriented analysis. On the basis of the evidence gathered, we will formulate a hypothesis about cultural values which (at least from the students' point of view) is in need of further corroboration. This requires a different pathway, known as ethnoaxiology, which will not be illustrated in this paper; a few pointers will be provided instead.
\end{abstract}

Keywords: ethnorhetorics; metaphor; Australian English; tall poppies; egalitarianism

\section{Introduction}

No 'fair dinkum' Australian is unfamiliar with the metaphorical meaning of the term tall poppy. Elsewhere in the English-speaking world, except in New Zealand, the tall poppy metaphor is not as solidly established; in the land down under, however, it appears to be

\footnotetext{
${ }^{1}$ The tall poppy phenomenon is a topic I have written about extensively in the past (Peeters 2003, 2004a, 2004b, 2004c), always with special reference to Australia. The current paper once again focuses on the land down under. I gratefully acknowledge permission to use the resources at the Australian National Dictionary Centre (Canberra).
} 
symptomatic of a widespread underlying cultural value. For migrants and overseas students, especially those whose first language is not English, this is important information; sadly, most EFL curricula, irrespective of the variety of English they impart, have little time for cultural values, focusing instead (apart from communicative competence) on "Culture with a capital C,” i.e., history, geography, cultural heritage, folklore, etc. This one-sidedness is also found in many other language curricula. It needs to be tackled head on, as it may result in severe culture shock when students and migrants travel to the country whose language they have studied. Applied ethnolinguistics (Peeters 2013, 2015) is a framework that has been developed to curb the trend.

Our aim is to show that in many instances--this being one of them--different ways of thinking and different cultural values appear to be tied up with different ways of speaking. A closer look at the tall poppy metaphor and at the most common phrases it enters into is therefore likely to increase our awareness of Australian cultural values. An exercise in ethnorhetorics such as the one we are about to embark on provides the structures and ideas for an enriching classroom experience, but not necessarily the material, which may have to be updated or freshly resourced to ensure its currency and relevance for language learners at the time of their learning. Ethnorhetorics is the applied ethnolinguistic pathway that takes a figure of speech (e.g., a metaphor) as its starting point, looks at how it is used and, on the basis of the evidence gathered, formulates a hypothesis which (at least from the students' point of view) is in need of further corroboration. In the case at hand, the hypothesis relates to the cultural value underpinning the Australian discourse about tall poppies. Its corroboration requires an ethnoaxiological approach (with ethnoaxiology being another branch of applied ethnolinguistics), which will not be undertaken here. A few pointers will be provided instead.

\section{Tall poppy testimonies}

Ethnorhetorics starts off with a sample of comments or testimonies providing a preliminary indication not only of the cultural salience of the figure of speech selected for scrutiny, but also of its meaning. The testimonies can come from cultural insiders (i.e., members of the languaculture), cultural outsiders (non-members), or both. In the case at hand, the former are native speakers of Australian English; the latter are non-Australians living in Australia or abroad. In what follows, we limit ourselves to testimonies from cultural outsiders contained in press articles written in a number of languages. 


\subsection{English language accounts}

Recent testimonies by cultural outsiders writing in English include those of Irishman John Masterson and US diplomat Joe Kaesshaefer:

I worked in Australia a good while back, and you used to hear a lot about the Tall Poppy Syndrome. Basically it meant that whenever an Aussie stood out from the crowd a bit there was a queue of people ready to chop them down to size. Maybe they got it from some of the Irish who went there a few generations back. (The Irish Independent, 22 September 2014)

[What are Australians like?] They are warm, and very American. They have similar ethics. They are very healthy and proud of their beach culture. Businesspeople often take their surfboards to the beach during lunch to catch a few waves. But be aware of "tall poppy syndrome.” The tallest poppy is the first to get its flower chopped off. That means, they don't like people who boast about their product or their business being the best. They appreciate when people are humble. (Triangle Business Journal [US], 19 September 2014)

Both passages draw attention to the so-called 'tall poppy syndrome' (see section 4.6) and use the verb chop to describe what it involves. Masterson's formulation is closer to the way 'real Aussies' talk (see section 4.5); Kaesshaefer's reference to boasting, on the other hand, is crucial for a correct understanding of the motives behind the syndrome.

\subsection{Foreign language accounts}

Cultural outsiders writing about Australia in languages other than English frequently refer to Australia’s tall poppy syndrome and/or provide definitions of what a tall poppy is. The following examples, all less than ten years old, are taken from (Brazilian) Portuguese, German, and Italian sources.

Suspeita-se que Chenoweth, um repórter de “The Australian Financial Review”, está se entregando a uma predileção jornalística nativa, a “síndrome de 'tall poppy”, pela qual os jornalistas ganham respeito depreciando grandes figuras públicas. (Valor Econômico, 19 January 2006) 
“One suspects that Chenoweth, a reporter for The Australian Financial Review, is displaying a native journalistic predilection known as the tall poppy syndrome, by which journalists gain respect through attacks on major public figures.”

Soziologen attestieren den Menschen in Australien ein “Tall Poppy”-Syndrom, Abscheu gegenüber Emporkömmlingen und Neureichen. Besonders erfolgreiche Australier geben sich deshalb lieber wie jedermann. Sie fahren keine Sportflitzer und machen sich nach wie vor die Hände am Grill schmutzig. (Die Welt, 25 October 2007) “Sociologists detect among Australians a ‘Tall Poppy’ syndrome, an abhorrence of upstarts and nouveaux riches. Particularly successful Australians therefore prefer to behave like everyone else. They do not drive sports cars, and they do get their hands dirty on the barbecue as they would have in days past.”

Il primo errore da evitare è quello che gli australiani indicano ironicamente con $i$ termini "the tall poppy syndrome", la sindrome del papavero alto, così chiamata perché ricorda la decisione del giardiniere che, di fronte a un giardino in cui non tutti i fiori sono alti uguali, pensando di renderlo più gradevole alla vista decide di potare quelli più rigogliosi e più forti ottenendo l'unico vero risultato di indebolire tutte le aiuole, lasciando crescere solo le piante mediocri. (Italia Oggi, 8 November 2007) "The first mistake to avoid is the one Australians ironically identify by means of the words tall poppy syndrome, so called because it records the decision of the gardener who, standing in front of a garden in which not all flowers are of the same height and thinking of making it more pleasing to the eye, decides to prune the lushest and strongest ones, thereby achieving just one real result: that of damaging all the flower beds, leaving only mediocre plants to grow.”

In Australien gibt es den Ausdruck “Tall Poppy Syndrome”. ... [Ein tall poppy] ragt aus dem Kornfeld heraus und wird daher am ehesten gekappt. In der Soziologie versteht man darunter eine erfolgreiche Person, die sich selber sehr exponiert darstellt und bei der man deshalb Schadenfreude verspürt, wenn sie letztlich doch fällt. (Welt Aktuell, 25 April 2013)

"In Australia, there is the term “Tall Poppy Syndrome”. A tall poppy protrudes from the cornfield and is therefore most likely cut. In sociology, the term refers to a successful 
individual who engages in over-exposure and is met with Schadenfreude when he or she ultimately falls.”

\section{Tall poppies in the Australian languaculture}

Tall poppies are found in many areas of public life, including the education system, business, politics, and sports.

\subsection{Tall poppies in the education system}

In Australia, intellectual achievement is often frowned upon, especially at pre-tertiary level. Both at the primary level (Burnett 2001; Burnett, \& Mandel 2010) and in secondary schools (Archard 2011), students who know all the answers and show too much enthusiasm are at risk of being ostracized by their classmates. Similar practices may well occur in other countries; however, in Australia more than elsewhere, they are likely to remain widespread and have the potential to persist throughout the entire education system as a result of adolescent exposure to the media (O’Neill et al. 2014: 212), which report on tall poppy behaviors whenever and wherever they occur.

This is not to say that the teachers themselves are entirely beyond reproach. Some of them may harbor their own "hostile views of gifted students" (Geake \& Gross 2008: 218); they may feel threatened by unusual talent and bear down on those who display it. Such attitudes have been documented for some time (see Peeters 2004a: 14--15). Although, in recent years, efforts to eradicate bullying by peers and teachers have been on the increase, psychological effects in later life remain commonplace, both in terms of the care taken not to shine above others and of the desire to criticize those who do.

\subsection{Tall poppies in the business world}

Business expert Jana Matthews deplores the reluctance of many Australian CEOs to share their success stories: “I don’t know if it’s [due to] 'Tall Poppy Syndrome',” she confided to the Australian Business Review Weekly on 22 October 2014. It probably is. In the past, many business leaders have paid the price for behaviors that single them out for attention and criticism (Peeters 2004b: 83), so much so that academic researchers are now increasingly documenting the rise and fall of the most notorious cases, e.g., Rodney Adler (see Cheng \& Seeger 2012) and Sol Trujillo (see Shields \& Harvey 2010). The former was a non-executive director of HIH Insurance, Australia's second biggest insurer, which collapsed in 2001; the 
latter, an American, served as the CEO of Australian telecommunications company Telstra from 2005 to 2009, a period during which the company's share price lost more than 25 billion dollars in value as a result of the global financial crisis of 2008--2009 and a failed bid for major infrastructure work all over Australia. Other examples of prominent business leaders who earned themselves a tall poppy tag include Christopher Skase, Rupert Murdoch, John Elliott, Alan Bond, and Gina Rinehart.

\subsection{Tall poppies in the world of politics}

Historian John Hirst (2009: 301--302) does not mince his words when describing how Australians tend to feel about politics:

Politics is necessarily about power, about inequality. In democracies those who exercise power gain their authority by the votes of the people. That inequality Australians are reluctant to recognise. (...) Australians will recognise that a boss or a military officer must have power, though they will respect him only if he exercises power properly. But politicians have no excuse for wanting power; they have wilfully put themselves above the rest. They will have trouble therefore in gaining respect, no matter who they are or what they do. Many Australians seem to think politics exists only because there are a few egomaniacs wanting to be politicians.

If Hirst is right, it is little wonder that federal politicians (especially prime ministers) are seen as providing the country's worst specimens of the tall poppy species. Large sections of the electorate love to hate them, either indiscriminately or more selectively (on the basis of political allegiance), mostly while they are in power, but sometimes also long after (see Terrill 2000: 77--117 and Peeters 2004a: 19--21, 2004b: 83--86 for a detailed look at a series of prime ministers including Robert Menzies, Gough Whitlam, Malcolm Fraser, Bob Hawke, Paul Keating, and John Howard).

\subsection{Tall poppies in the sports arena}

In spite of a widespread perception to the contrary, inspired no doubt by the country's love affair with sports, even Australia's top sports people are not immune from the tall poppy threat, as documented in Peeters (2004b: 76--83). At the very most, for reasons to do with merit, athletes and sports people are perhaps less likely to be treated as tall poppies and more 
likely to be celebrated than high achievers in other areas, in which status is often perceived to be undeserved, based as it is on power rather than skill.

There is, however, another factor at play as well. The different treatment enjoyed by many sports people also has to do with the well-known fact that Australians are able to identify with and be inspired by their sports heroes in ways they cannot identify with or be inspired by politicians or business leaders. They are less tempted to find fault with the former, but will happily scrutinize the latter. Regardless, Australia's sports stars are cut down if their countrymen feel there are reasons for them to be dealt with in this way. Cricket legend Don Bradman, tennis hero Pat Rafter, and swimming great Kieren Perkins, to name but a few, have all been referred to as tall poppies, but for their reputation at least there has been no long-term damage--something that cannot be said about others.

\section{Linguistic analysis}

We now turn our attention to language matters, and examine how Australian English captures the way its speakers think about tall poppies. Overall, the prototypical tall poppy very much remains an object of dislike in Australia. High achievers whose accomplishments are praised and who are treated with respect are not normally called tall poppies. The term is almost always reserved for those who are deemed not to deserve the respect that they, no doubt, think they do deserve. The analysis that follows will further corroborate these impressions.

\subsection{Tall poppies in Australian English dictionaries}

The forthcoming second edition of the Australian National Dictionary (AND) appears set to maintain the first edition's definition of a tall poppy as "a person who is conspicuously successful; freq. one whose distinction, rank, or wealth attracts envious notice or hostility” (Ramson 1988: 494). Research carried out in the last fifteen years suggests however that the "freq." which introduces the second part of the definition may well be an overstatement. It is certainly the case that envy has often been singled out by high achievers as a trigger for the treatment they receive; on the other hand, the idea that such treatment is frequently inspired by this dark force does have a certain currency among contemporary Australian academics (e.g., Moore 2010: 167--169), who have most likely contributed to spreading that view 
abroad. ${ }^{2}$ Regardless, envy is at best an occasional ingredient for the conferral of tall poppy status. O’Neill et al. (2014: 211) correctly point out that "tall poppy behaviors in Australian society range from resentment for authority, individual cultural and personal values and norms, to personal envy.” Feather and Nairn (2005: 88), for their part, report on research that found that "resentment rather than envy is the key variable in both the wish to see a tall poppy fall and the pleasure or schadenfreude that is experienced when that fall occurs.” In the case of politicians in particular, envy is not an issue at all: most Australians have no desire whatsoever to join their ranks (see section 3.3).

No reference to envy appears in the definition found in the sixth edition of the Macquarie Dictionary (Macquarie 2013: 1498). According to that definition, which was first used in the fourth edition (2005) and expands on earlier paraphrases, a tall poppy is "someone who is preeminent in a particular field; a person with outstanding ability, wealth, or status.” There are two parts to the definition, as in the AND, with a semicolon separating the parts. In both cases, we are dealing with a unitary concept, with the second part merely providing a different gloss or a different take: outstanding ability, wealth, or status are of course indicators of preeminence, and even though wealth is not limited to a particular field, outstanding ability and status usually are. The rather common pejorative connotation identified by the AND is totally absent.

Unlike the AND and the Macquarie Dictionary, Wilkes’ Dictionary of Australian Colloquialisms (Wilkes 2008: 288; henceforth DAC) isolates two meanings both carried over from earlier editions. The first, illustrated with quotes covering the years 1931 to 2001, refers to "a person with a high income"; the second, illustrated with quotes covering the years 1967 to 1991, refers to “anyone eminent in any way.” Earlier editions had limited the range of illustrative quotes for the first meaning to 1973, thereby creating the impression of a gradual shift in meaning. The update is welcome recognition of the fact that the first of the DAC's separate meanings is still with us today, especially whenever reference is made to a business leader or an entrepreneur. On the other hand, there is enough overlap between the two meanings to question the need to posit polysemy and to justify Ely’s (1984: 104) reference, based on an early edition of the DAC, to a single "basic connotation” involving “a person who, in an implied or stated context of activity, and on an implied or stated measure, stands

\footnotetext{
${ }^{2}$ For a recent example, see Gressel (2014: 63--77). Bruce Moore was director of the Australian National Dictionary Centre from 1994 to 2011.
} 
much higher than most others.” Once again, neither the DAC nor Ely (1984) refer to the pejorative connotation highlighted in the AND.

One last dictionary definition deserves a mention, even though it is less recent. Like the AND and the Macquarie Dictionary, Johansen’s (1996) Penguin Book of Australian Slang provides a two-part paraphrase (with an en dash serving as the separator). There is a reference to the pejorative overtone in the second part. Unlike the $A N D$, however, envy is not mentioned. Instead, the definition talks about a "very important person; influential person; person with status--often held in contempt by others, who try to bring about this person's downfall or ruin” (Johansen 1996: 414). Of all the dictionary definitions surveyed, Johansen's appears to be the most accurate, although it, too, remains incomplete.

\subsection{Tall poppies: a complementary historical sketch}

The oldest known usage, in an Australian print publication, of the term tall poppy referring to a person appears in an article titled “The 'honour' of knighthood,” published in the Sydneybased newspaper The Empire on 8 December 1864. The article (a reprint of a text originally published in The Saturday Review, a London weekly) presents the Order of the Garter, the oldest and highest British Order of Chivalry, as “a kind of public proclamation that you are a tall poppy”; it questions whether the Provost of Perth (Scotland) should have been admitted to the order, as was reported, simply for attending the unveiling of the statue of a British royal. The first two truly Australian uses of the term referring to a human being seem to go back to 1871. One of them is in a speech to the Legislative Council in Melbourne, printed in The Argus on 14 June 1871, in which James Wilberforce Stephen, who migrated from England in 1855 and was elected to the seat of St Kilda in 1870, drew attention to the "mode in which the Chief Secretary had kept his Government together”: "He had, as it were, taken all the tall poppies into his camp.” The other occurrence is quoted in section 4.5.2. Neither fits in well with the AND's idea of conspicuous success; instead, reference is made to (pre-)eminence, importance, influence, or status (the nouns used by the DAC, the Macquarie Dictionary, and Johansen 1996). Thus, the apparently more recent usage posited in the DAC actually predates the one referring to high income (which the AND traces back to 1902, the date of the first and oldest of its illustrative quotes).

According to the DAC (Wilkes 2008: 288), it was not until the 1930s that the term was given currency, thanks particularly to New South Wales premier J. T. Lang, who introduced a bill intended to put a cap of $£ 10$ a week on all government salaries. In a book published some 
forty years later, Lang (1970: 147) recalls how he "referred to those being paid more than that amount as the 'tall poppies'.” Understandably, the proposed legislation caused quite a stir, and the term, used on several occasions in the NSW Parliament and in the daily press, was all of a sudden here to stay--mostly with predominantly negative overtones.

Interestingly, though, as of the 1970s, efforts were made to reverse the negative overtones. The emblematic elevation of the so-called Flanders poppy, artificial specimens of which are commonly worn on Remembrance Day in commemoration of the Allied troops killed during World War I, possibly contributed to the spread of the so-called “commendative uses” (Ely 1984: 105) of an existing metaphor: after the war, the Flanders poppy had indeed "come to symbolize the warrior cut down in a good cause, and so could be easily extended as a symbol of hero-martyrs generally” (Ely 1984: 105). At the end of the 1980s, Australian sentiment about tall poppies became the topic of intense and pioneering research primarily carried out by social psychologist Norman Feather, who continues, in publication after publication, to use the term in a neutral way. For him, it is synonymous with the term high achiever; the two often appear together, linked by the conjunction or, and negative or positive overtones are contextually determined rather than inherent. Feather's references to "unpleasant” and "boastful” tall poppies are quasi-tautological; those to "quiet," "modest,” and "likeable” tall poppies are oxymoronic. ${ }^{3}$

The trend aimed at reversing the connotations of the term tall poppy continues to the present day, even though, in everyday Australian English, describing someone as a tall poppy remains far from a compliment. The ongoing trend is reflected in the Tall Poppies record label, the Cairns-based Tall Poppies band, and also the annual Australia-wide Tall Poppy Campaign. The latter is endorsed at the highest levels of government, but woefully underpromoted; in several Australian states, it has led to the establishment of an annual Tall Poppy Day and the conferral of Tall Poppy Awards as well as Young Tall Poppy Science Awards to the most deserving and most promising scientists--most of whom remain, however, less widely known than those who risk being referred to as tall poppies in the pejorative sense. Australians have never been known for giving their scientists the treatment they reserve for some of their politicians, entrepreneurs, and, to a lesser extent, sports people. They have been

\footnotetext{
${ }^{3}$ Feather's more recent work includes Feather and Nairn (2005), Feather (2006, 2008, 2015), Feather et al. (2013). For comments on earlier work, see Peeters (2004a/b).
} 
known for failing to give their men and women of science the recognition they deserve for the important role they play and the groundbreaking discoveries they make. ${ }^{4}$

One wonders whether it is the ongoing efforts aimed at a revaluation of the term tall poppy that have led Wierzbicka (2002: 1170--1171) to list the phrases "it is not very good to be a tall poppy" and "it is bad to bignote oneself” (italics added) among the best clues to "genuine Australian cultural scripts." Popular wisdom, she claims, "does not hold that it is bad to be a 'tall poppy' but rather, that it is not as good as 'some people' might think” (Wierzbicka 2002: 1170--1171). My own research suggests that, according to 'popular wisdom', it is as bad to be a tall poppy as it is to bignote oneself. The rehabilitation of the term tall poppy remains very much an uphill battle; its progress is slow and remains largely unnoticed. These days, the phrase tall poppy typically refers to status seekers who, on the basis of unwarranted selfadulation, itself a consequence of success, amassed fortune, or fame, have become a target for criticism; it also refers to individuals (most commonly business leaders) who, overcome by success, amassed fortune, or fame, and on the mistaken assumption that they are above the law, have engaged in unlawful behavior only to find that, eventually, the law catches up with them as well. Tall poppies tend to be seen as braggers and/or egotists, people who, to use an evocative French expression, fart higher than their arses. This kind of arrogance is ultimately what attracts the ire of the average Australian. Those who indulge in ego trips that are either too frequent or simply over the top soon meet with public wrath.

\subsection{Tall poppies: an explication in natural semantic metalanguage (NSM)}

The most common meaning, in Australian English, of the term tall poppy can be found in [A] below. [A] is a semantic explication formulated in NSM, an empirically tested, universally intelligible, and unambiguously translatable natural semantic metalanguage (NSM) intended to improve on the culturally specific descriptions that abound in the literature. The latest table of semantic primes can be found at the end of the paper; for more information on NSM, readers are referred to the introduction to this special issue. ${ }^{5}$

\footnotetext{
${ }^{4}$ The Tall Poppy Academy (Peeters 2004a: 7) now operates as the Enrich Management Group, a proprietary company listed on the stock market.

${ }^{5}$ [A] is based on an earlier explication (Peeters 2004b: 86) which also contains information reproduced not here, but in the cultural scripts in section 5 .
} 
[A] a tall poppy

a. someone of one kind

b. people can say what kind with the words tall poppy

C. someone of this kind often thinks like this:

d. "I am not like other people, I am someone very good, I am someone above other people

e. because of this, I can do many things very well

f. other people cannot do things like this"

g. at the same time, someone of this kind often thinks like this:

h. "I want other people to think the same about me"

i. it is bad if someone thinks like this

Components a and b describe a tall poppy as one type of person, identifiable through the use of the term tall poppy. Tall poppies experience a sense of importance, of superiority over others; they are unable to contain themselves and feel their achievements lend them a status and privileges that others do not have. Components c to h express the kinds of thoughts they harbor; these thoughts relate, on the one hand, to how they see themselves and to what they feel their special status entitles them to, and on the other hand, to how they want to be perceived by others. Component i spells out that these are bad thoughts; it is a direct reference to the Australian antipathy towards tall poppies in general.

\subsection{Why poppies?}

Why, of all things, did James Wilberforce Stephen, J. T. Lang, and others refer to tall poppies rather than any other kind of flowers (or anything else that sticks out)? The answer, which may surprise, brings us all the way back to Roman antiquity, to a story reported, among others, by Livy (Titus Livius, born around 60 BC, died 17 AD; for a list of other loci, see Peeters 2003: 25). The story involves Roman king and tyrant Tarquin walking down his garden and cutting down all the tall poppies within reach.

In recent Australian scholarship, the 'Livy connection' has been most forcefully argued by Murray-Smith (1989: 389), whose partly inaccurate reading of the ancient historian (for details, see Peeters 2003: 24) is less unexpected than his unverifiable claim that "many more Australians read Livy in the nineteenth century than do today.” Did they really? Or were they familiar with the story through alternative channels, such as English translations of the works of sixteenth-century French author François Rabelais, which may well have been more widely read in the southern hemisphere than Livy's 1,900-year-old History of Rome? But why would 
the story have appealed to an Australian public more than to the French, who have been exposed to it not only thanks to Rabelais's Le quart livre (chapter 63), but also thanks to Voltaire's Dictionnaire philosophique (s.v. emblème) and Alexandre Dumas père's Les Bourbons de Naples (book II, chapter 8)? The French phrase hauts pavots “tall poppies,” used by Rabelais, is uncommon to say the least, and has absolutely no metaphorical meaning. ${ }^{6}$

It is far more likely that nineteenth-century Australians knew about the story thanks to references to it in newspapers of the day. A few examples will suffice. On 16 December 1854, The Empire reported on the deadly effects of typhus and cholera, which, "besides weeding out from the soil of life the obviously diseased and debilitated, seem to take a malignant delight in striking at the apparently sound and fair--as if they had received the instruction given by the Roman tyrant, when he cut off the heads of the tallest poppies.” The Ovens and Murray Advertiser of 18 August 1860 recalled that "when Tarquin the Proud was asked what the best mode of governing a conquered city was, he replied to his interrogators by striking down with his staff all the tallest poppies in his garden.” The Empire again, on 12 May 1865, printed a letter to the editor in which it was said that "the attempt to deprive a large body of men among the most intelligent in the community of their political rights as citizens, reminds one of the Grecian usurper, who intimated his plan of operation by lopping off the heads of the tallest poppies in the garden.”

In Peeters (2003), I argued that the only commonality between the old story and modern Australian behavior is the image that is used. The meaning conveyed is not the same: whereas the ancient lopping of poppies was symbolic of murder, its modern counterpart involves no bloodshed whatsoever, so much so that tall poppies can occasionally make a comeback and scale new heights after having been cut down. Another difference is that in ancient times the parties involved were direct rivals, whereas nowadays we are dealing more often than not with attacks in a non-competitive situation, usually from a safe distance. I took all this as an indication that the connection was tenuous at best and that the common imagery was pure coincidence, since the poppy is a fairly common flower, with many varieties found in many parts of the world, including Australia. On current evidence, my earlier claim that the question

\footnotetext{
${ }^{6}$ This is unfortunate, in a way, because one is tempted to say, playing on words, that in many cases les hauts pavots tiennent le haut du pavé (i.e., tall poppies are leaders in their field). Les Bourbons de Naples first appeared in instalments in Italian, a language which, unlike French, has given the tall poppy metaphor a certain currency through the phrase alti papaveri.
} 
of the origin of the tall poppy metaphor has no answer other than the human tendency towards expressivity, and the natural reliance on common aspects of the human environment to service that tendency, is untenable. The 'Livy connection', however tenuous it may look, is real and not to be dismissed.

\subsection{Verb phrases involving tall poppies}

Unless stated otherwise, all examples quoted in this section and the next (sometimes with a few omissions) were found in Australian newspapers published in 2014. They are taken from press articles, letters to the editor, and other reactions from readers such as impressions left on newspaper websites and subsequently printed in the newspapers themselves.

4.5.1 Cut the tall poppies down (to size). Cut down--or cut down to size--is the verb most commonly associated with tall poppies in the Australian psyche.

(1) Cutting down a tall poppy is as Australian as enjoying a meat pie and a VB. (Geelong Advertiser, 11 July)

(2) In the days after one of the Liberal Party's tallest poppies, Sophie Mirabella, was cut down to size, her loss was attributed to the campaigning brilliance of a group of young Melbourne “hipsters”. (The Australian, 27 September)

Cut off is used as well:

$$
\begin{aligned}
& \text { We should not seek to cut off tall poppies who support our region. (Newcastle } \\
& \text { Herald, } 7 \text { January) }
\end{aligned}
$$

4.5.2 Other verb phrases. Commenting on the Irish uprising against union with England, Marcus Clarke, in his Old Tales of a Young Country (1871 [first edition], p. 197) talks about the tallest poppies among the Irish rebels being cropped first. Crop the tall poppies is the earliest known verb phrase with a meaning similar to the very common cut down the tall poppies, which appears to be more recent. Interestingly, the phrase crop the tall poppies is about as old as the earliest known genuinely Australian use of the term tall poppy referring to humans. It is still in use today. 
Knock is about as widespread as cut, especially if variants such as knock down, knock over and knock off are included:

(4) People should stop knocking tall poppies. (Daily Telegraph, 9 October)

(5) Isn't it time to give credit to Clive Palmer, the lad with big, original ideas for Australia? Or are we to knock down another tall poppy? (Herald Sun, 2 July)

(6) The Sharks are being portrayed as a basket case, but it is only a matter of time before they knock over a tall poppy. (Gympie Times, 27 June)

(7) Dragons' captain John Bullock came up with a plan to knock off the tall poppies and capture his Dragons side their first victory of the season. (Western Advocate, 19 March)

Many other verbs refer to some sort of severing. Besides cut down, cut off, and crop, we have prune, fell, lop off, mow down (illustrated in Peeters 2004a, 2004c), and also lop, chop, and chop down:

(8) Australians tend to be suspicious of overly confident or successful characters, and try to "lop the tall poppy", and prick the bubble of self-regard. (The Age, 19 October)

(9) Some suggested it was un-Australian of me to say [Cate Blanchett's] performance was not deserving of an Oscar; that I was just chopping down tall poppies. (Sydney Morning Herald, 5 March)

The majority of phrasal verbs involve the adverb down. Besides cut down, knock down, mow down, and chop down, we have bring down, pull down, put down, tear down (illustrated in Peeters 2004a, 2004c), and shoot down:

(10) Has the shooting down of tall poppies--the measles of Australia--spread overseas now? I think so. (Northern Territory News, 6 January)

Pull out is illustrated in Peeters (2004a, 2004c), which leaves topple: 
(11) Toppling tall poppies is not solely an Aussie pastime. There have been instances overseas. (Northern Star, 27 November)

More than twenty different verbs, all followed by the same noun phrase and referring to what is basically the same treatment, must be an amazing proliferation in anyone's books. And the list is probably not exhaustive.

4.5.3 The broader context. Australia's treatment of tall poppies is often depicted as a sport, a favorite sport (see Peeters 2004b: 83), or a national sport:

(12) Cutting down tall poppies was once considered a national sport, but Warrnambool College has embraced the term as a way of celebrating its alumni. (Warrnambool Standard, 14 October)

It has also been described as an “Aussie pastime” (example 11) and an Australian tradition:

(13) Maybe the reason against awarding knighthoods is that it will make that Australian tradition of cutting down tall poppies more difficult. (The Australian, 1 April)

(14) Seems the fine Australian tradition of cutting down tall poppies is thriving. (Gold Coast Bulletin, 3 March)

Noun phrases such as enthusiasm for, readiness to, tendency to, and love of, and verb phrases such as like to, be eager/prone/determined to, and be obsessed with, often surface in front of the verb phrases listed in sections 4.5.1 and 4.5.2. All of them were illustrated with examples in Peeters (2004a) and point in the same direction as the references to sport, pastime, and tradition.

\subsection{Nominal compounds}

Nominal compounds involving the term tall poppy include tall poppy syndrome, tall poppy stuff, tall poppy treatment, tall poppy mentality, tall poppy business, and probably a few more. Of these, tall poppy syndrome is by far the most common. It is singled out for further comment in what follows. 
4.6.1 Tall poppy syndrome. "Tall Poppy Syndrome (TPS), an Australian cultural expression, describes a 'disease' that feeds on the belief that anyone who appears to represent success, high ability, or admirable qualities must be attacked, demeaned, and cut down to the common level” (Mancl \& Penington 2011: 79). From a linguistic angle, regardless of the scare quotes, the reference to a disease in this American definition (based on Australian research by Norman Feather and myself) is quite appropriate. Historically speaking, the term syndrome was first used in the medical sciences, as early as the mid-sixteenth century, to refer to a number of symptoms occurring together. Its adoption by psychologists in the 1950s served as a trigger for a more widespread use, so much so that, nowadays, according to the American Heritage Dictionary of the English Language, the term is employed with reference not only to a complex of symptoms that, collectively, betray the presence of a disease, a psychological disorder, or indeed any undesirable or abnormal condition, but to any kind of distinctive behavioral pattern, such as TPS. ${ }^{7}$

Despite claims to the contrary (O’Neill et al. 2014: 211), there is no evidence to suggest that the term tall poppy syndrome goes back as far as the nineteenth century (unlike the base term tall poppy, which does). If such evidence were to surface, the history of the spread of the word syndrome would have to be rewritten. The earliest known use of the term can be found in the Canberra Times (13 September 1980), where it appears in the context of a rugby union grand final opposing two local teams:

(15) They go into the grand final with logic suggesting a win to Royals and almost overwhelming support for Wests. Which is a reversal of the role in recent years and probably reflects something of the tall-poppy syndrome, among other factors.

A longer phrase, cut-down-the-tall-poppy-syndrome, is included in the forthcoming second edition of the $A N D$, with a date of 1979. It has all the hallmarks of a hapax, without being one, as evidenced by an occurrence in the Queensland Times of 7 March 2014:

\footnotetext{
${ }^{7}$ Archard (2011), who has researched TPS in a secondary school setting (see section 3.1), mistakenly defines it as "the fear of standing out from the crowd." She turns the condition on its head. Top students who fear standing out from the crowd will tend to take precautions in order not to be cut down. Their fellow students are the ones who succumb to TPS, which consists in actively pursuing anyone who does stand out.
} 
(16) The cartoon depicting Cate Blanchett in a demeaning fashion post Oscars was a prime example of 'cutting down the tall poppy syndrome'.

The shorter and much more common phrase tall poppy syndrome can be further illustrated as follows:

(17) Australia has that tall poppy syndrome where if you get ahead of yourself there's always someone pulling you back down. (Sydney Morning Herald, 8 July)

(18) We need to lose the tall-poppy syndrome where success is criticised and viewed with suspicion. (The Australian, 21 August)

4.6.2 The broader context. A very common observation is that TPS is alive and well, or words to that effect (for more examples, see Peeters 2004a: 15--16):

(19) The tall poppy syndrome is alive and well, which is why I kept a low profile. (Sunday Magazine, 6 April)

(20) The Tall Poppy Syndrome is still well and truly alive in this country. (Northern Star, 18 October)

Not only is TPS alive and well, it is familiar, well-known, prominent, even world famous:

(21) The story of William Dobell is also an example of one of Australia's least attractive attitudes, that familiar tall-poppy syndrome. (Gold Coast Bulletin, 13 December)

(22) Our well-known "tall poppy" syndrome undermines the willingness many people in Australia feel to stand out from the crowd. (Sydney Morning Herald, 19 October)

(23) The tall poppy syndrome is so prominent in Australia. (Herald Sun, 12 June)

(24) She's not the first and certainly won't be the last to get a delightfully sour taste of our world famous Tall Poppy Syndrome. (Daily Telegraph, 7 August) 
It is a well-established part of Australia's DNA (Australian Financial Review, 29 March), something that is ingrained (Canberra Times, 11 October), hardwired into the Australian mind (Peeters 2004a: 14, 2004b: 79), embedded in the local culture:

(25) Mr Estens thinks it is a pity the tall poppy syndrome is embedded in the Australian culture. (Moree Champion, 3 February)

Phrases such as be a victim of or fall victim to the tall poppy syndrome are used either by self-proclaimed victims of TPS, or by the media when referring to a fall from grace:

(26) Northern Territory Minister Bess Price has lashed out at fellow indigenous MPs, saying she is a victim of the tall poppy syndrome. (The Australian, 29 March)

(27) He was elected president of the Australian Medical Students’ Association but fell victim to the tall poppy syndrome when some saw his enthusiasm as arrogance. (The Advertiser, 28 December)

\subsection{Tall poppies must be cut down: an NSM explication}

To cap off our linguistic analysis, we provide an NSM explication of the phrase Tall poppies must be cut down. Strictly speaking, far from being synonymous, cut, chop, lop, mow, prune, and all the other verbs documented above mean different things (for NSM explications of the verbs cut and chop, see Goddard \& Wierzbicka 2009). However, regardless of whether tall poppies are cut, chopped, lopped, mowed, pruned, or whatever, the outcome is the same. Differences that matter at a non-metaphorical level cease to be relevant when we are dealing with a metaphorical interpretation.

\section{[B] Tall poppies must be cut down}

a. everyone knows:

b. it is bad if someone thinks like this:

c. "I am not like other people, I am someone very good, I am someone above other people

d. because of this, I can do many things very well

e. other people cannot do things like this"

f. I say:

DICTUM

g. "when someone thinks like this, other people cannot not say some bad things about this someone"

h. this is like 
i. when the top [m] of some flowers [m] of one kind is far above the top [m] of other flowers [m] of the same kind in the same place

j. people cannot not do something to these flowers [m] when it is like this

k. people do it with something sharp [m]

I. after this, because of this, the top [m] of these flowers [m] touches the ground [m]

Explication [B] builds on proposals for explicating active metaphors made in Goddard (2004). Whereas it seemed to make sense not to explicate the term tall poppy with reference to "flowers of one kind” (most native speakers of Australian English, when identifying a tall poppy without making any determination on its fate, would not even think of a flower with a stem longer than the norm), it does not seem right to avoid referring to flowers when explicating an assertion such as Tall poppies must be cut down. Verbs such as cut, chop, lop, etc. add an extra dimension to what is otherwise a relatively unimaginative description: it is as though, all of a sudden, speakers kick new life into a lexicalized metaphor whenever they choose to combine that metaphor with a verb that only makes sense when the metaphor is interpreted in a non-figurative way.

There are three parts to explication [B], referred to as SHARED KNOWLEDGE, DICTUM and COMPARISON. Components a to d make up the SHARED KNOWLEDGE section, which provides knowledge about tall poppies and how people feel about them. Components e and $f$ make up the DIctum, where we find an explication of what is actually said, namely, that those who brag about their achievements must be dealt with appropriately. Components g to l account for the comparison which is implicit in the metaphor. This part of the explication makes use of a few semantic molecules (top, flower, ground, sharp), which is to be expected (Goddard 2010) in the case of NSM explications involving either concrete nouns (such as poppy--the flower), physical activity verbs (such as cut), or both.

\section{A cultural value up for scrutiny: egalitarianism}

What can foreign language learners seeking to acquire advanced linguistic and sociocultural competence in Australian English learn from the widely held view that Australians suffer from tall poppy syndrome and tend to cut their tall poppies down? A detailed ethnorhetorical study of the tall poppy metaphor must inevitably lead to the conclusion that there is an important Australian cultural value at play here, which advanced students will no doubt be able to identify using terms such as equality or egalitarianism. 
On the basis of the evidence gathered, the assumed cultural value is but a hypothesis in need of corroboration (see below). However, as it turns out, there is a large body of literature pointing to or dealing with Australian egalitarianism, or indeed the lack thereof. Historian John Hirst (2009: 301) provides a good starting point to make sense of this contradiction:

Some people claim that Australian society is not egalitarian because there are wide differences of income, which may now be getting wider. This misses the point of Australian egalitarianism. It is the way Australians blot out differences when people meet face to face. They talk to each other as if they are equals and they will put down anyone claiming social superiority. It is the feel of Australian society that is so markedly egalitarian, not its social structure.

Hirst has repeatedly identified Australian egalitarianism, a long-standing part of Australia’s social fabric, as an “egalitarianism of manners” (e.g., Hirst 1988: 74, 1998: 208, 2009: 172). Egalitarianism, Australian style, does not mean that Australians are discouraged from reaching for the stars, provided ambitions, once achieved, do not result in arrogance or a display of superiority. Nor does it mean there is anything wrong with the pursuit of success, provided it goes hand in hand with an awareness that nobody is entitled to special status once success has been achieved. Generally speaking, Australians do not resent success, whether it be their own or someone else's. What they do resent is success and achievement going hand in hand with the conspicuous bragging and egotistical behavior that turns a high achiever into a (prototypical) tall poppy. This is expressed in cultural scripts [C] to [E]:

[C] A cultural script for a characteristically Australian social attitude towards other people
a. many people here think like this:
b. it is good if someone can think like this about other people:
c. "these people are people like me
d. I I am not someone above these people, these people are not people above me"

[D] An Australian cultural script discouraging positive feelings of 'specialness'
a. many people here think like this:
b. it is bad if someone thinks like this:
C. "I am someone very good
d. I Im not like other people" 
[E] An Australian cultural script discouraging the urge to be the object of other people's positive feelings of 'specialness'

a. many people here think like this:

b. it is bad if someone thinks like this:

c. "I want other people to think about me like this:

d. this someone is someone very good, this someone is not like other people"

Scripts [C] to [E] build on formulations originally proposed by Wierzbicka (2002: 1194-1195) and updated by Goddard (2006: 68, 2009: 42). Component d in script [C] was added for further clarity, in line with Goddard (2012: 1040). While script [C] refers to the Australian preference for being socially similar, scripts [D] and [E] are indicative of its discomfort with any presumptions of superiority. They translate into a behavioral norm which requires Australians to downplay their achievements, and which can be explicated as in [F].

\section{[F] Thou shalt not be a tall poppy}

a. sometimes, people think like this about someone:

b. "this someone is not someone like me

C. this someone often thinks like this:

d. "I am not like other people, I am someone very good, I am someone above other people

e. because of this, I can do many things very well

f. other people cannot do things like this"

g. when people think like this about someone, they feel something bad

h. they do not want this someone to be like this

i. because of this, they say some bad things about this someone

j. after this, because of this, this someone is like all other people

Explication [F] clearly shows that the Australian norm Thou shalt not be a tall poppy is primarily about unacceptable behavior attributed by the majority to specific individuals one does not like to identify with, viz., so-called tall poppies. Components a to f set the scene: to understand what the norm involves, we need to first imagine a tall poppy. Components g and h point out how people feel when they see or think of one. Components i and j refer to how the norm is enforced and to the result of its enforcement. 
Further evidence for scripts [D] to [F] can be found in "Australian words and expressions like to bignote oneself, a tall poppy, to cut down tall poppies, to knock down, knockers, and so on” (Wierzbicka 2002: 1195). Goddard (2012: 1045) points out that “statements about one’s personal abilities are liable to violate cultural proscriptions favouring maintaining the appearance of modesty and cautioning against the possibility of being seen as 'blowing one’s own trumpet', having a 'big head', being ‘up oneself', a ‘wanker', etc.”8 In Australian English, it is commonly said that tall poppies are too big for their boots or that they need to pull their head in. Failure to do so may result in high achievers being targeted by TPS; as pointed out by Goddard (2006: 68), “conspicuous self-promotion, efforts to impress, or merely seeking recognition of one's special achievements are likely to win only scorn in the Aussie ethos ... while conversely efforts at modesty and self-deprecation are admired.” Pomposity, self-adulation, and the desire to impress are all cardinal sins in a country where not taking yourself too seriously (Goddard 2009; Sinkeviciute 2014) is an important cultural norm, which differs from the norm or norms that exist elsewhere in the Anglo world, even though the same or similar words are used. No matter how successful Australians are, their ultimate aim must always remain to be like everyone else, not to assume they are special and not to expect anyone else to assume this about them.

From an applied ethnolinguistics point of view, the words and phrases listed above can be put to good use in an ethnoaxiological corroboration of the cultural value of egalitarianism: their negative connotations, which (unlike those of the term tall poppy) remain strong and stable, can be seen as additional evidence in favor of that cultural value, which is very prominent in the Australian English languaculture. There are many other forms of linguistic and non-linguistic evidence that could be used; among the most striking are the "solidarity practices” (Goddard 2006: 68) observed not only in informal settings (e.g., shortened given names such as Libs and Loz for Libby and Lauren, or modified surnames such as Jonesie and Fergo for Jones and Ferguson) but also in selected formal environments (e.g., the insistence

\footnotetext{
${ }^{8}$ AusE wanker comes from the colloquial verb wank "masturbate." Stollznow (2004: 7) notes that "due to [the] original reference to sexual gratification becoming analogous to 'satisfying' one's ego and vanity by bragging," wank and being a wanker are now metaphors referring to "behaviour that is egotistical and self-indulgent.” Her list of related verbs includes to be full of it and to have tickets on oneself; she also quotes the acronym figjam (i.e., fuck I'm good just ask me) (Stollznow 2004: 8).
} 
on the immediate use of first names, even when, strictly speaking, a relationship is set to remain 'vertical' for quite a while to come). ${ }^{9}$

For now, the conclusion must be that the detailed cultural and linguistic study of an Australian phenomenon as obvious as TPS is bound to draw our attention to (or remind us of) the Australian aversion for conspicuous pride or ambition, or for any form of behavior that someone either feels entitled to, or expects to get away with, on the basis of success. It can teach us a few invaluable lessons about what is arguably one of the most prominent cultural values in the minds of most Australians, viz., egalitarianism.

\section{References}

Archard, N. (2011). Peer influence on female student leadership attainment, capacity and development: A staff and student perspective within a girls' school context. Leading and Managing, 17(1), 1--15.

Burnett, P. C. (2001). Elementary students’ preferences for teacher praise. Journal of Classroom Interaction, 36(1), 16--23.

Burnett, P. C., \& Mandel, V. (2010). Praise and feedback in the primary classroom: Teachers' and students’ perspectives. Australian Journal of Educational \& Developmental Psychology, 10, 145--154.

Cheng, S. S., \& Seeger, M. W. (2012). Lessons learned from organizational crisis: Business ethics and corporate communication. International Journal of Business and Management, 7(12), 74--86.

Ely, R. (1984). Australian historians on 'tall poppies’: A survey. Australian Cultural History, 3, 104--126.

Feather, N. T. (2006). Deservingness and emotions: Applying the structural model of deservingness to the analysis of affective reactions to outcomes. European Review of Social Psychology, 17(1), 38--73.

\footnotetext{
${ }^{9}$ I remember very vividly the shock I felt, almost thirty years ago, as a newly arrived international postgraduate student at the Australian National University, when expected to call the head of department and my academic supervisor by their given names, within seconds of being introduced to them. I soon found out that, in Australia, this is very much the done thing (see also Goddard 2012: 1041).
} 
Feather, N. T. (2008). Effects of observer's own status on reactions to a high achiever's failure: Deservingness, resentment, schadenfreude, and sympathy. Australian Journal of Psychology, 60(1), 31--43.

Feather, N. T. (2015). Analyzing relative deprivation in relation to deservingness, entitlement and resentment. Social Justice Research, 28(1), 7--26.

Feather, N. T., \& Nairn, K. (2005). Resentment, envy, schadenfreude, and sympathy: Effects of own and other's deserved or undeserved status. Australian Journal of Psychology, 57(2), 87--102.

Feather, N. T., Wenzel, M., \& McKee, I. R. (2013). Integrating multiple perspectives on schadenfreude: The role of deservingness and emotions. Motivation and Emotion, 37(3), 574--585.

Geake, J. G., \& Gross, M. U. M. (2008). Teachers’ negative affect toward academically gifted students: An evolutionary psychological study. Gifted Child Quarterly, 52(3), 217--231.

Goddard, C. (2004). The ethnopragmatics and semantics of 'active metaphors'. Journal of Pragmatics, 36(7), 1211--1230.

Goddard, C. (2006). 'Lift your game Martina!’: Deadpan jocular irony and the ethnopragmatics of Australian English. In C. Goddard (Ed.), Ethnopragmatics: Understanding discourse in cultural context (pp. 65--97). Berlin: Mouton de Gruyter.

Goddard, C. (2009). Not taking yourself too seriously in Australian English: Semantic explications, cultural scripts, corpus evidence. Intercultural Pragmatics, 6(1), 29--53.

Goddard, C. (2010). Semantic molecules and semantic complexity (with special reference to “environmental” molecules). Review of Cognitive Linguistics, 8(1), 123--155.

Goddard, C. (2012). 'Early interactions’ in Australian English, American English, and English English: Cultural differences and cultural scripts. Journal of Pragmatics, 44(9), 1038--1050.

Goddard, C., \& Wierzbicka, A. (2009). Contrastive semantics of physical activity verbs: 'Cutting' and 'chopping' in English, Polish, and Japanese. Language Sciences, 31(1), 60-96.

Gressel, J. (2014). Embracing envy: Finding the spiritual treasure in our most shameful emotion. Lanham: University Press of America.

Hirst, J. (1988). Egalitarianism. In S. L. Goldberg, \& F.B. Smith (Eds.), Australian cultural history (pp. 58--77). Melbourne: Cambridge University Press. 
Hirst, J. (1998). Egalitarianism. In G. Davidson, J. Hirst, \& S. Macintyre (Eds.), The Oxford companion to Australian history (pp. 208--209). Melbourne: Oxford University Press.

Hirst, J. (2009). Sense and nonsense in Australian history. Melbourne: Black Inc.

Johansen, L. (1996). The Penguin book of Australian slang: A dinkum guide to Oz English. Ringwood: Penguin Books.

Lang, J. T. (1970). The turbulent years. Sydney: Alpha Books.

Macquarie dictionary. (2013). (6 ${ }^{\text {th }}$ ed.). Sydney: Macquarie Dictionary Publishers.

Mancl, A. C., \& Penington, B. (2011). Tall poppies in the workplace: Communication strategies used by envious others in response to successful women. Qualitative Research Reports in Communication, 12(1), 79--86.

Moore, B. (2010). What's their story? A history of Australian words. Melbourne: Oxford University Press.

Murray-Smith, S. (1989). Right words: A guide to English usage in Australia. Melbourne: Viking.

O’Neill, M., Calder, A., \& Allen, B. (2014). Tall poppies: Bullying behaviors faced by Australian high-performance school-age athletes. Journal of School Violence, 13(2), 210-227.

Peeters, B. (2003). The tall poppy syndrome: On the re-emergence in contemporary Australia of an Ancient Greek and Latine motive. Classicvm, 29(2), 22--26.

Peeters, B. (2004a). Tall poppies and egalitarianism in Australian discourse: From key word to cultural value. English World Wide, 25(1), 1--25.

Peeters, B. (2004b). 'Thou shalt not be a tall poppy': Describing an Australian communicative (and behavorial) norm. Intercultural Pragmatics, 1(1), 71--92.

Peeters, B. (2004c). Tall poppy stuff. In B. Lewandowska-Tomaszczyk, \& A. Kwiatkowska (Ed.), Imagery in language: In honour of Professor Ronald W. Langacker (pp. 613--623). Frankfurt: Peter Lang.

Peeters, B. (2013). Language and cultural values: Towards an applied ethnolinguistics for the foreign language classroom. In B. Peeters, K. Mullan, \& C. Béal (Eds.), Cross-culturally speaking, speaking cross-culturally (pp. 231--259). Newcastle-upon-Tyne: Cambridge Scholars Publishing.

Peeters, B. (2015). Language, culture and values: Towards an ethnolinguistics based on abduction and salience. Etnolingwistyka, 27, 47--62. 
Ramson, W. (1988). The Australian National Dictionary: A dictionary of Australianisms on historical principles. Melbourne: Oxford University Press.

Shields, J., \& Harvey, A. (2010). Succumbing to the burden of foreignness: A social constructionist analysis of Australian print media representations of Telstra CEO Sol Trujillo. Management Communication Quarterly, 24(2), 288--321.

Sinkeviciute, V. (2014). “When a joke’s a joke and when it’s too much”: Mateship as a key to interpreting jocular FTAs in Australian English. Journal of Pragmatics, 60, 121--139.

Stollznow, K. (2004). Whinger! Wowser! Wanker! Aussie English: Deprecatory language and the Australian ethos (pp. 1--11). In C. Moskovsky (Ed.), Proceedings of the 2003 Conference of the Australian Linguistic Society. Retrieved from: http://www.als.asn.au

Terrill, R. (2000). The Australians: The way we live now. Sydney: Doubleday.

Wierzbicka, A. (2002). Australian cultural scripts--bloody revisited. Journal of Pragmatics, 34(9), 1167--1209.

Wilkes, G. A. (2008). Stunned mullets \& two-pot screamers: A dictionary of Australian colloquialisms. (5 ${ }^{\text {th }}$ ed.). Melbourne: Oxford University Press. 
Appendix--Semantic primes (English exponents), grouped into related categories

\begin{tabular}{|c|c|}
\hline I, YOU, SOMEONE, SOMETHING THING, PEOPLE, BODY & substantives \\
\hline KIND, PART & relational substantives \\
\hline THIS, THE SAME, OTHER ELSE & determiners \\
\hline ONE, TWO, SOME, ALL, MUCH MANY, LITTLE FEW & quantifiers \\
\hline GOOD, BAD & evaluators \\
\hline BIG, SMALL & descriptors \\
\hline KNOW, THINK, WANT, DON'T WANT, FEEL, SEE, HEAR & mental predicates \\
\hline SAY, WORDS, TRUE & speech \\
\hline DO, HAPPEN, MOVE & actions, events, movement \\
\hline BE (SOMEWHERE), THERE IS, BE (SOMEONE/SOMETHING) & location, existence, specification \\
\hline (IS) MINE & possession \\
\hline LIVE, DIE & life and death \\
\hline $\begin{array}{l}\text { WHEN TIME, NOW, BEFORE, AFTER, A LONG TIME, } \\
\text { A SHORT TIME, FOR SOME TIME, MOMENT }\end{array}$ & time \\
\hline $\begin{array}{l}\text { WHERE PLACE, HERE, ABOVE, BELOW, FAR, NEAR, } \\
\text { SIDE, INSIDE, TOUCH }\end{array}$ & place \\
\hline NOT, MAYBE, CAN, BECAUSE, IF & logical concepts \\
\hline VERY, MORE & intensifier, augmentor \\
\hline LIKE AS WAY & similarity \\
\hline
\end{tabular}

Notes: - Primes exist as the meanings of lexical units (not at the level of lexemes) • Exponents of primes may be words, bound morphemes, or phrasemes • They can be formally complex • They can have language-specific combinatorial variants (allolexes, indicated with $\sim$ ) $\bullet$ Each prime has wellspecified syntactic (combinatorial) properties. 